\title{
XXXIX. An account of a few independent notices of America by middle-age writers
}

\author{
J.O. Halliwell Esq. F.R.S. F.S.A. F.R.A.S.
}

To cite this article: J.O. Halliwell Esq. F.R.S. F.S.A. F.R.A.S. (1839) XXXIX. An account of a few independent notices of America by middle-age writers, Philosophical Magazine Series 3, 15:96, 284-285, DOI: $10.1080 / 14786443908649878$

To link to this article: http://dx.doi.org/10.1080/14786443908649878

册 Published online: 01 Jun 2009.

Submit your article to this journal $₫$

Џll Article views: 2

Q View related articles 두 
284. Mr. Halliwell on Notices of America by Middle-ageWriters. $\frac{1}{2}$ an inch in diameter. I slightly moisten the interior of the tube with distilled water, not allowing the hands or fingers to come in contact with the water: the tube thus prepared is to be held vertically over the apex of the jet of burning gas. By these means a strong solution of the substance is obtained, and which may be tested with perfect ease by Hume's test, or any other of the usual tests employed for arsenic, \&c.

I hope that the foregoing process will be found to possess all the delicacy and precision necessary for distinguishing these two bodies from each other, and that it will be the means of removing every doubt from the minds of the experimentalist in future.

Royal Arsenal, Woolwich, June 21, 1839.

J. M.

XXXIX. An Account of a ferw Independent Notices of America by Middle-age Writers. By J. O. HaLliwell, Esq., F.R.S., F.S.A., F.R.A.S., \&c.*

I $\mathrm{N}$ the notes to the new edition of the Travels of Sir John 1 Maundevile, I slightly noticed a very singular passage, which bears evidence of a far higher degree of geographical knowledge than the Englishmen of the fourteenth century have hitherto had credit for. I give it here at length in modern phraseology.

"In that land, nor in many others beyond, no man can see the star Transmontane, which is called the Star of the Sea, or Pole-Star; but men see another star, the contrary to it towards the south, and is called Antarctic. And this is because the world is of round shape, for the part of the firmament that shows in one country, does not show in another country. And men may well prove by experience and subtle trial of intellect, that if a man would search the world and find passage by ships, men might go by ships all about the world, both beneath and above. [He then gives his astronomical reasons, for which I refer to the work itself.] By the which I tell you certainly that men may environ all the earth, beneath and above, and return again to his own country, whoever had company and shipping, and alroays he roould find men, lands, isles, as roell as in this country."

Maundevile afterwards proceeds to relate a story, which he had heard when young, of a traveller who from India got to Norway, and found several countries in his way. He also adds that there are more than five thousand islands beyond India, which shows that there was a very general notion of the extent of land in the western world.

- Communicated by the Author. 
Mr. J. H. Rigg on a Corollary by Prof. J. Thomson. 285

In the work of Ethicus on geography, said to be translated by St. Jerome, and if so of a very early perion, reference is made to the existence of large islands in the Atlantic Ocean. It may also be remarked, that there are several tales extant, as early as the fifth and sixth centuries, in which are mentioned several instances of seamen having been driven greatly out of their course from the coast of Spain, and reaching districts never previously visited by Europeans; the Saxons even were accustomed to go to Rome all the way by sea, and it is not unlikely that some of them may have traversed the Atlantic: otherwise how can we account for the general notion which certainly did exist of a country far to the westward beyond the sea, and not coincident with the eastern boundaries of the Old World ?

The terrestrial paradise of the middle-ages may possibly have been America; Maundevile, who we must remember was travelling towards the east, describes it as being situated far beyond India. Again, we could hardly expect that the Chinese had not, from a remote period, the knowledge of the existence of a continent in such a relative position to them; and this may account for the tradition current in the East, and a further confirmation of which was not likely to be obtained from that people. From the obstacle thus placed to the free discussion of discovery on the eastern boundary of the Old World, and the difficulty of proving by experience any isolated facts obtained primarily from the vicissitudes of the sea on the western, it is not surprising that we find legend on the one hand and uncertain tradition on the other.

It may be necessary to observe that the preceding notices could have no reference whatever to the discovery of America by the Northmen in the tenth century.

XL. On the Corollary deduced by Professor J. Thomson, from the Proposition demonstrated by him in the Number for July. By James H. RrgG.

To the Editors of the Philosophical Magazine and Journal. Gentlemen,

YOUR insertion of the following correction of part of a 1 communication which appeared in your last, in an early Number of your Magazine, will oblige yours truly, July 20, 1839.

JAMES H. RigG.

Professor Thomson gives and demonstrates the following Prop. "Let $A$ B C be a $\Delta$, and through any point $P$ in its plane, let A D, B E, C F be drawn, cutting the sides, or the sides produced in $\mathrm{D}, \mathrm{E}, \mathrm{F}:$ through $\mathrm{D}, \mathrm{E}, \mathrm{F}$, desc. $a b$ 